\title{
Axiology and Agathology
}

\section{Vladimir K. Shokhin*}

Institute of Philosophy, Russian Academy of Sciences

Moscow, Russian Federation

Received 05.04.2020, received in revised form 27.07.2020, accepted 10.08.2020

\begin{abstract}
From the very beginning, attention is given to the fact that, being introduced at the very beginning of the $20^{\text {th }}$ century, the axiology term, meaning the doctrine of values, almost immediately led to a boom in the development of theories of values (mainly in continental philosophy), whereas the agathology term, meaning the doctrine of goods, which was introduced in 1770 and then rediscovered in 1823, came to almost complete oblivion. For its rehabilitation, one of the commonplaces of the philosophy of the $20^{\text {th }}$ and $21^{\text {st }}$ centuries is reviewed, namely, the actual identification of goods and values, as a result of which the former of these concepts is absorbed by the latter. As for values, they are also usually viewed as common human needs, rather than deep and indivisible individual "inner possessions". Therefore, it is proposed to distinguish between universal needs and personal valuables and to stratify the world of significant things into values, preferences, and goods. As a result, the latter of these varieties is interpreted as a sphere of practical mind (both in the Ancient and Kantian senses), teleologically loaded and with the potential to be included in a new, the fourth of the large programmes of theoretical ethics (able to compete well with consequentialism, deontology, and virtue ethics) and, at the same time, laid into the foundation of the cluster of philosophical disciplines, which is commonly termed as practical philosophy.
\end{abstract}

Keywords: values, preferences, goods, ethics, practical philosophy, axiology, agathology, heart, taste, practical mind.

Research area: philosophy.

Citation: Shokhin, V.K. (2020). Axiology and agathology. J. Sib. Fed. Univ. Humanit. Soc. Sci., 13(8), 1370-1383. DOI: 10.17516/1997-1370-0648.

(C) Siberian Federal University. All rights reserved

* Corresponding author E-mail address: vladshokhin@yandex.ru 


\section{Very different fate of "close relatives"}

The fact that axiology in the first half of the $20^{\text {th }}$ century became one of the most rapidly developing brands of continental philosophy is probably known to relatively many people. Yet, the fact that the very term axiology itself (from the Greek $\dot{\alpha} \xi i \alpha$ "value" + $\lambda$ ó $\gamma$ os "word, doctrine") was forged only at the beginning of the same century in France (by Paul Lapi in 1902) and in Germany (by Eduard von Hartmann till 1906) and soon received its "permanent residence" in philosophy is known to relatively few. As for the fact that the related meaning of

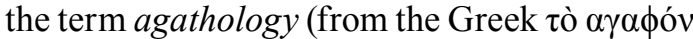
"good") was used in ethics much earlier (by the Lutheran theologian Christoph von Ammon in $1823^{1}$ ) and in practical philosophy even earlier (by the Wolffian philosopher Johann Feder in $1770^{2}$ ) to sink into oblivion, to be mentioned sometimes only in old lexicons, and to be rediscovered only in the $21^{\text {st }}$ century in some cases without the slightest suspicion that it has its past ${ }^{3}$, it is probably known only to singular historiographers. The reason why agathology did not survive Ammon was probably because of the lack of a philosophical rating and due to the fact that his "doctrine of the highest good" was inserted in confessional (Lutheran) ethics. And the reason why it was not "pulled to the surface" in the era of the axiological boom and much later is primarily due to the fact that the goods were practically not distinguished from the values, and of these two concepts, the latter has been regarded much more modern, "promoted" $"$ and, therefore, supposedly able to

\footnotetext{
1 His "Textbook on Christian moral teaching" contained a separate (third) section "Agathology, or on the highest good" (Agathologie, oder von dem höchsten Gute) (Ammon, 1823: 214-259).

2 In "The textbook on practical philosophy" (1770), he divided the subject matter of this discipline into Agathologie (the doctrine of goods), Telematologie (the doctrine of will), and Nomologie (the doctrine of laws). The first teaching was described in $\S \S 18-23$ (Feder, 1770: 23-51).

3 Refer to: (Shokhin, 2004; cf. Shokhin, 2014; Delcomminette, 2006). A Prague philosopher coined the term "agatheism" to refer to his theological doctrine (see, for example, Salamon, 2017).

4 Approximately fifteen years ago I wrote: "The word values is one of the most prestigious and respectable in modern cultural vocabulary. At the same time it is one of the most popular or even "populist" as one might say. A political figure who wants his words to be taken more seriously will prefer to say
}

naturally incorporate the former. And why, in fact, as Occam has already stated, unnecessarily multiply entities?

\section{Problematic synonymy}

This moment has been always crucial. If the identification of the good with the desirable is very common, but not universal, and is deservedly problematic after George Moore, then the identification of goods with values is almost universal. These concepts alternate in a lot of philosophical texts only for stylistic reasons for the most part. The main reason is that these concepts are very similar to each other (such as "civilization" and "culture", "transcendent" and "transcendental", "philosophy of religion" and "religious philosophy", for example). And what is similar is conveniently rounded up to synonymy.

However, it is not today when the merging of these related concepts began and was installed in the philosophical and academic environment. It is worthwhile dwelling upon the epoch of the initial formation of axiology again. In Friedrich Kirchner's popular Lexicon of Basic Philosophical Concepts, revised by D. Michaelis (1911) "value is an effective ability of things to become goods for the people

that he offers a certain programme for the implementation of national or, on the contrary, international, pluralistic, or even, on the contrary, global values as it is now customary to say. The editor of a magazine preparing an advertising announcement will say that its authors appeal to the reader for whom liberal or, on the contrary, traditional values are significant or close (or both, as it often happens in our country). A writer or a director informing about his plans in an interview will almost certainly mention that he sees his task as promoting people's awareness of genuine social, aesthetic, or common cultural values (and, most often, all of them together). And a bank or other commercial enterprise that invites you to buy its shares will sometimes present the case in such a way that only the holders of its securities can understand what "true values" are. As a result, the word we are interested in undergoes a clear degradation, turning from a term of theoretical reflection into an "iconic" word of everyday language" (Shokhin, 2006: 7). All this remains valid for the present time when the research of what is sometimes a little tastelessly termed the "axiosphere" in all areas of life from the so-called sociological values (housing, work, wages, recreation, etc.) to gender ones is in full swing. "Value systems" of a wide variety of respondents in all parts of the world are regularly calculated by such "sociological giants" as the World Values Survey (WVS), and provide good grants to numerous armies of sociologists in the main countries of the world. 
worthy of aspiration". Everything that a person feels impelled to, wants, and sets as a goal is a value for him/her. Although goods, according to Kirchner, as we have just seen, correlate with values like the determining and the determined, the good itself is designated as everything that a person attaches value to, since it promises him/her pleasure whether in memory, in pleasure proper, or in anticipation (Kirchner, 1907: 1095, 375-376).

Yet, lexicons can only reflect what already exists in the philosophical culture. One of the first scholars who gave an authoritative definition of value was the theorist of the Austrian economic school Friedrich von Wieser (a student of $\mathrm{K}$. Menger, its founder and one of the strongest critics of Marx), who wrote a special monograph "On the origin and basic history of economic value" (1884). "Value (Wert)", according to Wieser, "is the human interest, which is thought of as the 'state of the goods' (Zustand der Güter)". In his Introduction to Philosophy (1895) which went through as many as 12 editions, Oswald Külpe, the founder of the Würzburg school of psychology, while mapping philosophical disciplines, O. Külpe considered it possible (as many others before and after him) to distinguish not only objective values (the value of money, for example, that one can get) and subjective values (personal preferences), but also positive and negative ones (Wert / Unwert), which are equivalent to goods (Güter) and, accordingly, non-goods (Übeln). "If something satisfies someone or if something is preferred to something," says Külpe, "it is a (relative) value or good. And if it leaves someone unsatisfied or even rejected, it is a negative value or evil". They also correspond to pleasure and aversion, happiness and misery, honour and contempt etc. (Külpe, 1910: 233-235). In the book The Idea of Value, which is often quoted in modern English-language philosophical literature, John Laird considered it most correct to present the concept of value through the selective approach. The selective conception assumes an approach to any value $X$ as a good from a certain point of view (timologically) ${ }^{5}$ as to an irrespective good

\footnotetext{
5 It should be clarified that meant is use of the Greek word $\tau \bar{\imath} \mu \eta$ with the meaning of "reverence", "high appreciation", "honour", and "value".
}

(as if, according to the old expression, $\mathrm{X}$ were a good in the eyes of God). But the good, in its turn, is defined by Laird through value: the good is either a character or a property of value. To say that beauty is or contains good is to say that the good has value, and to say that love is the greatest good is to recognize it as the greatest value (Laird, 1929: XVII, 321-322).

This "circular relationship" between value and good has been pointed out by such an astute critic of axiology as Martin Heidegger. In his lectures on European nihilism in the early 1940s, where Nietzsche's "re-evaluation of higher values" was very sympathetically interpreted, Heidegger unobtrusively demonstrates that the concept of value itself is logically a "non-reference" one: the good is usually defined through value, which, in its turn, is defined through the good, and such is the relationship of value with the concepts of significance, purpose, and foundation. In short, axiology revolves in logical circles and, claiming to interpret the entire world culture, is not the best product of the second half of the $19^{\text {th }}$ century only (Heidegger, 1997: 45, 47-48).

In Heidegger's assessment of the concept of values, there was a lot of sharpness. He wrote that being a sort of pseudo-concepts for this reason, "values" are also responsible for an individual's pseudo-existence: they made the mankind believe in the idea that any attempt on them threatens to destroy its existence, but, in fact, value is just a weak and leaky cover for "the objectivity of things that has lost its volume and background", since it is responsible for the fact that a person lives his/her 'pseudo-life' while measuring and calculating everything, and this pseudo-existence is comparable to Plato's cave, from which the true human existence must be "extracted". There is a certain contradiction in these harsh cavils: a concept, which, according to Heidegger, is so "weak and leaky", can hardly exert such a powerful influence on humanity and keep it under such a strong hypnosis (therefore, it should not be compared with Plato's cave, but rather with the Advaitic Māyā). However, in his verdict on

\footnotetext{
6 Refer to (Heidegger, 1997: 47) for the fact that the definition of value of something is inseparable from comparing things with each other through "weighing" them.
} 
the circular definitions of values and goods (as well as related concepts), he was undoubtedly right. In analytical philosophy, however, the problem noted by him was not given due attention. This contradicts to the analytical method itself, which should first of all be aimed at demarcating the concepts under the research. Below are just a few specimens.

Thus, in the article "The Theory of Value", Thomas Hurka, a renowned Canadian ethicist and political philosopher, who is in a certain sense "responsible" for axiology in modern analytical practical philosophy, interprets the doctrine of value, or, of the good (which means the same for him) as one of the two main branches of ethical theory alongside the "theory of the right". His article starts with the "postulate of identity" in the field under the discussion: "The theory of value or of the good is one of the two main branches of ethical theory, alongside the theory of the right. Whereas the theory of the right specifies which actions are right and which are wrong, the theory of value says which states of affairs are intrinsically good and which intrinsically evil. The theory of the right may say that keeping promises is right and lying wrong; the theory of value can say that pleasure is good and pain evil, or that knowledge and virtue are good and vice evil. Since these states are not actions they cannot be right or wrong, but they can have positive or negative value" (Hurka, 2007: 357).

In his book The Theory of Virtue: Excellence in Being for the Good, the authoritative American theologian and philosopher Robert Adams distinguishes between the types of goodness, insisting, for example, that it is not enough to characterize the virtue simply as the good. Thus, perfection for Adams is equivalent to intrinsic goodness. Yet, the world of the goods, according to Adams, is partly diversified: the differences in temperament, experience, vocation, moral and religious views are likely to make some people more susceptible to some goods, and others to other goods (Adams, 2006: 186). However, Adams also suggests identifying types of goodness or, equivalently, value. Thus, utility is a purely instrumental goodness or value that something has as a means to something else that is good or valued.
E.J. Bond, the author of the article "Theories of Good" for the second edition of the L. and S. Becker's famous ethical lexicon (2001), is also well known among the ethicists, as is his book on the related topic Ethics and Human Well-Being (1996). He distinguishes between functional goodness (with syncagorematical meaning of 'good food', 'good knife', 'good doctor', etc.) and goodness in its proper sense, which belongs to life, honour, pleasure, etc. There is, however, one thing that is the highest good, such as pleasure, for example. In general, the good (or the highest good) can be spoken of in various ways, but the good as such is something that has value in itself and for itself, regardless of its relation to anything else, or, in another way, it is the "intrinsic value" (Bond, 2001: 620).

In one of her articles, American Kantian Christine Korsgaard, the author of Creating the Kingdom of Ends (1996), suggests distinguishing several subject fields. In the section "Differentiations of the good" of her survey "Theories of the Goods", the most significant of them, according to Korsgaard, is the distinction between the things that are valued as means, or "instrumental goods", and as ends, or "final goods". This distinction is indistinguishable from another one - between internal and external values. To say that something is intrinsically valuable is to say that it is good because it is due to its intrinsic nature, whereas to say that something is externally good is to say that it is good because of its relations to the things outside of it. The means, for example, have an obvious external value, since their goodness comes from the fact that they contribute to other things, whereas the ends have an intrinsic value. Goodness can also be divided into objective and subjective. It is worthwhile regarding them as the goodness for everyone and the goodness for someone, even though the goods and values are viewed as interchangeable concepts. In Korsgaard's point of view, philosophers of the $20^{\text {th }}$ century discussed the issue of their relationship as per the following propositions: 1) the good is something "inherently subjective", and people have a reason to strive for common objects only when their interests coincide; 2 ) subjective val- 
ues always serve the basis for objective ones (if it is subjectively good for me to have something, it is objectively good for me to have it); 3) some subjective values, such as those related to needs, are basic for the objective ones, others are not; 4) subjective values are always basic for the objective ones (if it is subjectively good for me to have something, then it is objectively good for me to have it); 5) subjective values are derived from the objective ones (I cannot insist that something is good for me because it makes me happy if I do not consider my happiness objectively good) (Korsgaard, 1998: 132). In other words, "values" can be substituted for "the goods" in absolutely any position and nothing will change from this.

A slightly different map of contemporary discussions on the issues related to the good is drawn in Johan Bränmark's review article "The Good" (2006). The author, who is also quite close to deontology ${ }^{7}$, divides the differences between ethicists in connection with the concept of the good (what does it mean to be good?) and the conceptions of the good (which things are really good?) ${ }^{8}$. Scrutiny of the concept of the good begins only with Moore, of the conceptions already with antiquity. Considering the issue of whether the good is a single concept, Bränmark claims that for Franz Brentano and many others this question would have been rhetorical, but gradually it ceased to be so, while Peter Geach proposed to distinguish between predicative and attributive use of the concept of the good. So, if the proposition " $X$ is $A B$ " is used predicatively, then it can be divided into " $X$ is $A$ " and " $X$ is $B$ ", and if this is impossible, then $A$ is used attributively. When applied to goodness, the judgments like "This is a good event" will be predicative, and the judgments like "This is a good knife" will be attributive. Whereas Aristotle leaned toward an attributive

\footnotetext{
7 Deontological ethics proceeds from the fact that the norms of correct action are set by the performance of duty and based on obligations. This differs it from consequentialist ethics with consequences of actions as a criterion, primarily in the form of individual and social benefits. It also differs from aretaic ethics with the criterion corresponding to virtues and, in some cases, directly to personified moral models. Ultimately, deontological ethics goes back to Kant.

8 In his discussion of evaluative concepts, he refers to John Rawls.
}

understanding of the good and Moore toward a predicative one, Geach believed that "good" is always an attributive adjective, since nothing is just good. Bränmark argues that the predicative use of "good" corresponds to the indication of "value", while the attributive one does not (Korsgaard, 1998: 151).

This does not mean that there are no voices against this identification. Yet, they are very rare and not always intelligible. Thus, T.J. Higgings, the author of the article "Moral Good" for the "New Catholic Encyclopedia" (2003), in its conclusion complains that the concept of good is now almost replaced by the concept of value and that both concepts are thought to be almost identical. Intrinsic values encompass truth, beauty, talent, health, peace, morality, and religion. Value, therefore, encompasses the entire spectrum of human desires and interests, rather than individual actions and objects of desire. But in this case value, according to the author, covers less than good (Higgings 2003: 354).

Higgins's complaints are quite justified: according to a well-known law of logic, the larger the scope of a concept is, the poorer its content becomes, and the inflation which "the values" $"$ are subject to cannot but affect (as in the case of any defaults) the neighbouring categories as well and the coin called "the values" in modern culture, becomes worn-out. And this is not the opinion of the author of these lines alone. The oldest American axiologist of the $20^{\text {th }}$ century, Abraham Edel, noted the success of the "general theory of values", designed to unite all normative philosophical disciplines from ethics to the philosophy of religion. Long ago, he wrote that "descriptively, a man's "values" may refer to all his attitudes for-or-against anything" (Edel, 1953: 198). Later, he stated that "its influence dissipated... when the use of the term "value" became so trivial and lost any definite meaning" (Edel, 1992: 1269).

\section{Listening to the language}

I think that implementation of "anti-inflationary measures" should begin first of all by following the advice of the same critic of classical axiology, Heidegger, who strongly recommended listening to the language that he, as

\footnotetext{
Refer to Note 4 above.
} 
we know, even considered "the abode of Being". This course of action will not contradict Moore's intuitionism, from which meta-ethics as such begins. So, in my opinion, the Russian language has some advantages in the area under study, and the opinion that it should only be a borrowing party is unfounded. Thus, this language does not need to resort to special lexical constructions to distinguish between dobro (approximately "benignity", "benevolence") and blago (the good), which was done in his time by Kant, who did not become consistent here. In Russian, they are differentiated naturally - both morphologically and grammatically: one can form a plural from blago, but one cannot form a plural from dobro. This corresponds to "the things themselves": there are many goods, but there is only one "benignity" equal to itself. But benefits from the language are waiting for us in the case of values as well.

The fact is that there is no lexical difference between "value" and "value/cost" in the languages of economically more developed cultures. Value/cost is lexically the same not only in English. German Wert, Swedish värde, French valeur, Spanish valor, Italian valore, etc. also have the same initial commodity meaning, which makes it difficult to distinguish it from "good (beneficial) things". And the fact that "the borders of my world are the borders of my language" (as another notorious philosopher of the $20^{\text {th }}$ century noted) is convincingly evidenced by the history of practical philosophy. Thus, not least of all, Thomas Hutcheson's approaches to calculations of the goods ${ }^{10}$ were due to the fact that in English the word "goods" means not only "the benefits" but, and in the first place, simply the "commodity". In utilitarianism, consideration of goods as a 'commodity' item was "substantiated" with both the worldview and the vocabulary since Jeremy Bentham, the founder of utilitarianism and Hutcheson's follower ${ }^{11}$. Yet, value means

\footnotetext{
${ }^{10}$ See, e.g., his opus magnum "A System of Moral Philosophy" (published posthumously in 1755), where calculations of public goods and "estimation of the value of this life" along with measuring of corresponding evils are undertaken (Hutcheson, 1755: 101, 223 etc.).

${ }^{11}$ See his detailed calculations of intensivity, duration, reliability narrowness and other indexes of pleasures (i.e. values) and pains (non-values) in his An Introduction to the Principles
}

"the importance or worth of something for someone" only in its secondary sense, whereas it is "cost" in the primary one. Is it surprising that goods and values are perceived (as fractions with the same denominator) as almost indistinguishable? The genius of the Russian language is that it is the only one of the cultural priorities in which stoimost' ("cost") and tsennost' ("value") are also distinguished lexically (as well as dobro and blago, see above), and the spirit of the language makes it possible to distance the cost-for-all and the value-for-someone. That is why a closely related word is $d r a-$ go-tsennost' ("what is most valuable"), which means not something that has a good value/cost in general, but something extremely precious for someone personally. However, in his time it was Kant who distinguished "Wert" from the word "Würde" than he did with the case of good). Nevertheless, the second word does not mean value in the specified hue of personal drago-tsennost' but in the general meaning of "dignity" (Russian dostoinstvo $=$ Roman honestum), which all men possess as humans in contrast to things.

This, of course, does not mean that there are no correspondences to the values, understood this way in Western languages, at all. In French, the word drago-tsennost' ("valuable") corresponds to "objet précieux" with the ad-

of Morals and Legislation published in 1780 (Bentham, 1859: 15:17).

12 In his Lectures on Ethics $(1775$ - 1781), Kant used the expression der Wert der Person, but in his Groundwork of the Metaphysics of Morals (1785) he already wrote: "In the kingdom of ends everything has either a price (Preis) or a dignity (Würde). What has a price can be replaced by something else as its equivalent; what on the other hand is raised above all price and therefore admits of no equivalent has a dignity". What refers to universal human inclinations and needs has a "market price" (Marktpreis); our individual life events, i.e. what corresponds to a certain taste or disposition for the play of the senses (in other words, the aesthetic sphere of life) - the "affective price" (Affectionspreis); what constitutes the condition under which it is only possible for something to be an end in itself, i.e. to have not a relative value (price), but an internal one, is dignity (Würde). Explaining what is said by the examples, Kant illustrates the "market price" by skill and diligence, the "affective price" by wit, vivid imagination, and gaiety, and what has "intrinsic value" - by loyalty to a promise and benevolence from principle rather than from instinct (Kant, 1903: 434-435). For the evolution of Kantian interpretations of "value" in general, one could refer to the detailed study in (Shokhin, 2006: 289-334). 
jective bearing the main semantic load. The same meaning is carried by the English adjective "precious", the Italian "prezioso", and the German noun "Schatz". However, the situation is more complicated with the corresponding abstract nouns: for example, the French "préciosité" means just the opposite of "the value" ("zhemannost", "manernost", "vychurnost"), whereas there are no such nouns in English and German. At least, I have not found such ${ }^{13}$. That is why the desired place in axiological vocabulary is firmly fixed by value/cost.

But one can listen to another language, primary to Russian and all the languages mentioned above. In the Gospel of Matthew, there are two shortest neighbouring parables obviously relating to the issue discussed here. In one of them the Kingdom of heaven ( $\beta \alpha \sigma i \lambda \varepsilon^{\prime} \alpha \tau \omega v$ ouj $\alpha v \omega v)$ is likened to the person who found, somehow, a treasure hidden in a field $(\theta \eta \sigma \alpha v \rho \omega$ $\kappa \varepsilon \kappa \rho v \mu \mu \varepsilon ́ v \omega \dot{\varepsilon} v \tau \omega \dot{\alpha} \gamma \rho \omega)$, which a man found and hid, and for joy over it he goes and sells a 11 that he has and buys that field (Matthew, 13: 44). The same Kingdom is likened to a mer-

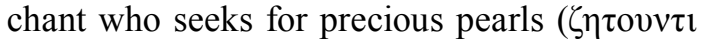

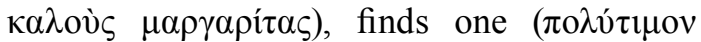
$\mu \alpha \rho \gamma \alpha \rho i ́ \tau \eta)$, sells all he has again and buys it (Matthew, 13: 45-46).

In the first case, a person does not take any action, but, having seized his sokrovishche (treasure / $\theta \eta \sigma \alpha v \rho o ́ \varsigma$ ), hides it as his (and only his) highest prize, and his joy in acquiring it is inseparable from concealment. In the second case, he carefully and purposefully "selects" riches, tests them and makes investments in what seems to him more promising than others. Etymologically, sokro-vishche ("treasure") is something that is carefully hidden ${ }^{14}$ and, therefore, it is in a certain sense synonymous with drago-tsennosti ("valuables") as something desired and causing almost ecstatic joy. It should be on the "field" that contains values and which is the field of the heart. The search for good pearls and selection of the best ones will correspond to understanding of the good, which,

\footnotetext{
13 They can, however, be constructed so that there will be something like calque from Russian, for example, in the form of inner possesion.

14 These shades are not found, for example, when this Evangelical noun has the form of trésor, treasure, and Schatz.
}

already among the Stoics, corresponded to "what is worthy of selection" ( $\alpha \rho \rho \varepsilon \tau$ óv), i.e. the choice made by another "part of the human", this part being practical mind ${ }^{15}$. However, in contrast to blagopriobreteniya ("benefits"), the "treasures" which the New Testament refers to are far from unambiguous. Jesus Christ says, according to the same Evangelist, that the good

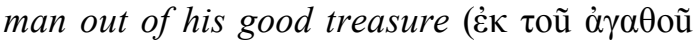
$\theta \eta \sigma \alpha u \rho o u ̃) ~ b r i n g e t h$ forth good things: and

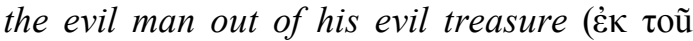

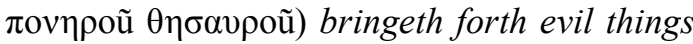
(Matthew, 12: 35). And when he says that where the treasure ( $\theta \eta \sigma \alpha u \rho o ́ \varsigma)$ is, there also will your

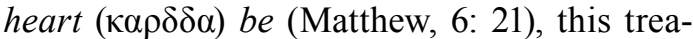
sure is not only localized in the heart, but it is also warned that the soul will take its main internal wealth, accumulated during life, with it, this wealth being possibly very different.

Listening to the language as a starting point for further research also corresponds to the very ancient universal idea that words correspond to the essence of things. However, it corresponds well to modern epistemology, in particular to epistemological fundamentalism with the ethical intuitionism as one of its branches. The essence of the ethical intuitionism is that the discourse begins not with the syllogisms but with those basic perceptions, visions, knowledge, without which the syllogisms would have to rely on other syllogisms, these syllogisms relying on the next ones and so on until the regress to the infinity (not to say into the void). From this launching platform, we can estimate how "values" have been understood (in main lines) in the history of philosophy, attempt at somewhat different approach, and, on this basis, design other adjacent territories of the intentional subject.

\section{How the world \\ of personal significancies is constituted?}

In 1785, in his The Groundwork of the Metaphysics of Morals Immanuel Kant introduced a very expressive but ambiguous concept of "a kingdom of ends" (ein Reich der Zwecke),

\footnotetext{
${ }^{15}$ This is how Antipater of Tarsus (the $2^{\text {nd }}$ century BC), a disciple of Diogenes of Babylon, defined the good according to the "Eclogues" of the early Byzantine encyclopedist Stobaeus (Stobaeus II.5.5 i).
} 
which, on the one hand, corresponds to the set of special goals that each human being sets for $\mathrm{him} /$ herself, on the other hand, - to the understanding of these very beings as goals-in-themselves in their community ${ }^{16}$. In both cases, we are dealing with a reflection of a purely rationalistic anthropology, which reduces the essence and nature of a man to mere goal-setting and leaves that complex inner world of the individual behind the scenes (as if these were only "empirical remnants"). Whereas Kant divided the world into the spheres of nature and freedom, his distant follower Heinrich Rickert in his Manifesto "Vom Begriff der Philosophie" (1910) - into the areas of reality (Wirklichkeit) and significancies (Geltungen) ${ }^{17}$. He populated the latter with the values (he wrote that the essence of value is its significance), having "edited" Kant's Kingdom of Ends as the Kingdom of Values.

However, in addition to Kant, Plato was also reliably present in his picture of the world, since this self-sufficient kingdom is as ontologically separated from our world as the hierarchy of eidoses is separated from earthly things. Being values-for-themselves (for example, in the form of scientific truths that are not discovered yet), Rickert's values are located on the other side of both objects and subjects, and the philosopher constantly emphasized their "non-psychological nature". Yet, at the same time they "affect" humanity (in a sense as Kantian things-in-themselves "affect" our experience), revealing themselves in its history in the form of primarily cultural values (there are, however, both cognitive and ethical ones which are also non-subjective). There must be some connecting links between us and these values. The latter have the form of the goods (Güter), which both belong to reality (as, for example, canvas, varnish, paint) and are carriers of the values (as, for example, their manifestation, such as an artistic work $)^{18}$. For Rickert, this dualism had a programme meaning in the context of its specific "science education": all areas of

\footnotetext{
16 Refer to: (Kant, 1903: 433-434).

17 Listening to the language again, one make sure that English significancies not too easy could be appropriated for conveying Geltungen. The same is true with French significativité or Spanish significado which are not capable to form a plural. 18 Refer to: (Rickert, 1910).
}

reality, in his vision, have long been divided by certain sciences, and philosophy should become the only "science of significances". The same correlation of eidetic, non-objective values and their empirical carriers (goods) was also perceived outside the Baden school - in phenomenology, as can be seen from the works by Max Scheler, Nikolai Hartmann, and, later, Roman Ingarden.

Having worked with these concepts for a long time, I firmly believe that the introduction of Geltungen into the philosophy of neo-Kantianism was highly constructive, and their interpretation as non-subject-object ones was absurd. To say that something is significant without specifying for what or, more importantly, for whom it is significant, is the same as to say that a certain segment of the path is simply "equal" (without specifying to what) or "more" or "less" (without specifying than what) or, when using philosophical and theological language, that something is coessential (also without specifying towards what). The same applies to the value: the irrelevant statement "Man is the highest value" without specifying for whom (Kant was one of the first to formulate such a proposition), will, as I have already repeatedly noted, be neither true nor false, but meaningless, whereas such a statement as, for example, "Spencer Tracy was the highest value for Katherine Hepburn" 19 is not quite correct (it would be more correct to specify it with "the feelings for Spencer Tracy" or "the rendezvous with Spencer Tracy"), but it is quite meaningful. Therefore, I found it necessary to clear the "significances" from all "non-psychological" (just as Rickert cleared them from all "psychological") and then raise them into a general concept describing the world of an intentional personal subject - the world that can and should be further stratified.

But first, it is important to understand one thing. The reason why "values" became "our all" to the enthusiasm of the majority and the frustration of the minority is very simple. It is their populist understanding, which is the exact opposite of Rickert's one. The world and national sociological services work so "suc-

\footnotetext{
19 Just in case, we mention the primary Hollywood stars of the $1940 \mathrm{~s}-1960 \mathrm{~s}$.
} 
cessfully" with them (see above) because they do not distinguish them from natural human needs, which are both universal and unlimited. But while natural needs of human beings can really be "calculated" in the manner of Bentham (see above), it is more than difficult to do this with personal values. They can only be compared with each other, first of all, according to the degrees of their "separability" and intersubjectivity, which implies much more.

In fact, we mean fairly transparent things. If we continue to use the example already given, it is possible to assume that although it made a certain amount of difference to Catherine and Spencer what brands of cars they used or from whom they ordered their suits, the significance of these artifacts for them was probably still not comparable to the significance of their feelings after their first rendezvous. And if this is true, then the designation of the significance of both types as values (which in the Russian language associate with 'drago-tsennosti' (valuables) see above) seems to me to be a "devaluation" of the latter, which is not justified by the degree of intensity of this inflation (due to the philosophers' reluctance to work with their language). Therefore, I would leave the nomination of values for the values of the second kind only and designate the first as preferences shared by many people with us and used by store advertisers (from book stores to meat stores) for selling products, by homeopathic doctors for a typology of people, by sociologists for their surveys, by politicians for their promises, and so on. In personal significances at the level of preferences, the intentional subject (which must necessarily be distinguished from other ones, primarily from the cognitive one) is entirely defined by his/her interests and tastes, and since we are similar in this with a great number of representatives of our kind, they will be "divisible" or shared by us with many and even with very many.

The case with significancies that I would regard as values as "inner possessions" and that the same individual with preferences has got but without which he/she would seem to lose his/her very personal core is opposite. This modality of significancies is localized in what might be called the keys, the innermost folds of the heart. Friedrich Eduard Beneke, the now completely forgotten German philosopher who justly rebelled (along with many others) against Kant's anthropological rationalism, very aptly called them "the spaces of bliss" (Lusträume) (Beneke 1828: 136).

On the psychological level, everyone can easily find out their actual values and not just preferences through introspection: by viewing those "contemplations" that they would not like to share with others; the feelings that they would betray themselves if they communicated them to someone else (it is worthwhile remembering 'sokro-vishcha'); deep expectations that they are passionately afraid to "jinx", etc. All this very intimacy defines the boundaries of the value in the meaning discussed. On the essentialist level, the values could be regarded as pure particulars that have the characteristics of "indivisibility", in the sense that they cannot be shared with anyone: they belong either to this subject, and to him/her only, or (if they are profane) to no one at all. To have someone else's values in this sense is just as impossible as to live or die for someone because it is about the uniqueness of hearts but not about social and other sensory characteristics. The case does not change when the same "value referent" can be an object for several subjects: their heart constitutions (in which this value is localized) are particular "by creation" 20 .

As for the goods, we deal here with a much more complex modality of personal significancies than the two under consideration, since it borders on both and, differing from them essentially, has a lot in common with them. Values are the sphere of the heart, preferences are the sphere of taste and interest, and in this case the question is primarily about practical reason, which the Greeks already knew well before Kant (cf. the first of the cardinal virtues

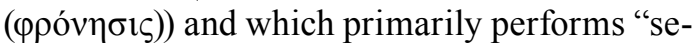
lection functions" concerning the objects of desire $^{21}$. The individual's agathological practi-

\footnotetext{
${ }^{20}$ For example, although Suzette Gontar should have been of interst and attractive not to the unfortunate Friedrich Hölderlin alone, who served her husband, it was for him only that she was Diotima. Thus, the forced separation from her directly accelerated his mental illness development.

${ }^{21}$ One text of much importance in this regard contains several definitions of the good, including the definition of the good
} 
cal mind can evaluate his/her preferences and values (if he/she has any control over his heart), ranking the former and trying to justify or, on the contrary, "neutralize" the latter (the heart's desires are very different). At that, this mind proceeds from certain norms, therefore, not only from what is desired, but also from what is due, and if it is endowed with a deeper reflection, then from system normative representations, and, if further, from the worldview ones.

This, however, does not mean that this practical reason is only a judge of interests and hearts: it "takes into account" the former and cannot do without the consent, "confirmation" of the latter. As for the "divisibility", the goods can be ranged between values and preferences: we strive for the goods that are common to both groups of people and even the entire human race, yet, at the same time everyone constructs their own ones (which makes the creativity of the "agathological subject"). The latter point is also associated with their "active modality": we give preferences to something, we experience our "inner possessions", and, due to the normative aspect of the goods, we strive to implement them in our lives and (if we are not moral autists) to "convert" others to them and, therefore, their intentionality is intersubjective. Hence it is clear that of all the layers of significance these are the goods that are ethically relevant. This cannot be said of the other two. But it is also possible to understand why public goods are possible, which every morally adequate person is obliged to contribute to in one way or another by conscience ${ }^{22}$.

Compared with other modes of personal significancies, this "activity" of the goods in combination with their "reasonableness" provides a specific modality of their hierarchy. Values as treasures and the desires of the heart

as what corresponds to the instructions of mind and, thus, for each individual the good will be something that the mind points out to regarding each particular case (Arist. Rhet. I. 6. 1362a 21-28)

22 There is a rather pathetic, but by no means meaningless expression of the famous philosopher Ivan Ilyin. According to the philosopher, values are what a person is ready to die for. Most likely, it should not be so much about the values as about the goods. These were freedom and other public goods that some great Romans or resistance heroes during World War II were willing to die for (and did it). are either absolute or none. Preferences as matters of tastes and interests are too ephemeral for consistent stratification. Yet, the world of the goods not only allows for significant gradation in the subject's consciousness but is constituted by it in a certain sense.

The matter is a specific teleology inherent in this world, which was noted by Aristotle with his normative distinction of the goods as means and the goods as ends. The goods of gymnastics is a means for good health, the goods of family life - for harmonic inner state, a trip to some country for participation in the prestigious conference can be a means for such a greater good as being employed in a certain position in academic circles to advance certain "good ideas" in the society, a successful deal for such a greater good as participation in charity, etc. With this "ladder" it is quite natural for practical mind (if it is, of course, endowed with the ability to contemplate) to raise the question of the highest good (summum bonum), which can no longer be a means for any other. Otherwise, "blago-polaganie" ("good-belief") will be only instinctively rational but not reasonable in the proper sense. This is fully recognized in modern literature on various branches of practical philosophy.

Much less attention is paid to the verticality of goods which results from the hierarchy in human nature itself. In this case, the Platonic-Aristotelian hierarchy (external, physical, and spiritual goods) has not lost its relevance either and can only be completed if based on the theistic picture of the world. And it would be possible to distinguish the prevailing common goods on each tier. Thus, we should distinguish the goods that arise from the ability to dispose of certain property from the external goods, the goods that arise from health from the bodily goods, the goods of the opportunities to develop skills (the highest of which are, of course, creative ones), and it is most likely that those goods that come from disposition to contemplation (what the ancients philosophers were absolutely right in) and to moral activity (what they have paid less attention to) are to be favored among the spiritual goods. Yet, for truly religiously gifted people there are "talents" which are obtained by grace and should be put 
into growth (cf. Matthew, 25: 14-30, Luke, 19: $11-28)^{23}$. Those involved in practical philosophy pay usually little attention to this vertical, since contemporary philosophical community teaches people think mainly horizontally, within the framework of evolutionary anthropology.

Another feature of this modality of significances is connected with temporality. Language does not prevent us from talking about both temporary and eternal, "imperishable" goods located beyond the borders of this earthly life, whereas the value experiences of the heart can be primarily thought of as temporal and the taste preferences as contingent only.

There are also certain "qualitative" differences between the three modalities of personal significancies highlighted here. Preferences can be very different in their merits (someone likes to watch classical opera, someone likes to watch football, and someone likes to watch snuff movies), and, therefore, it is said that tastes differ, although they can be evaluated from an ethical or cultural point of view. Values can be both mostly life-fulfilling and absolutely fatal for a person (if, for example, his/her whole heart lies near a roulette table or a slot machine). But false or illusory goods (to which both Feder and Ammon, the first systematizers of agathology, paid great attention to) are self-contradictory concepts. The division into objective and subjective, which is very popular at the present time, does not apply to the goods either. But here they do not differ from other modalities of significances, to which this divi-

\footnotetext{
${ }^{23}$ In contrast to the ability to paint, write poetry, do mathematics, etc., religiousness in one form or another is inherent in man as such, as evidenced by the absence of completely irreligious periods in the history of mankind and the fact that even the most anti-religious ideological systems have denied religion in the name of some sort of quasi-religion. According to John Calvin, who relied on the patristics and ancient thought (historical proof of the existence of the divine world based on the universality of the worship of God among both the Hellenes and the barbarians), a man comes into the world not as a "pure board", but as a being endowed with such an "instinct" as divinitatis sensus ("the sense of the divine"). At present, this Calvinistic idea has been consistently developed by such a famous analytical philosopher as Alvin Plantinga. The abovementioned parable of the talents, according to which one person was given five talents, another - three ones, and a third person - only one talent without further profit, also indirectly indicates that there are no people who are completely devoid of this "sense of the divine" but not all try to realize it.
}

sion does not apply in principle. The fact that I have individual goods (the goods for me only) does not make them merely subjective, since their belonging to me is quite an objective fact, and quantitative indicators cannot determine transition from the subjective to the objective. The goods are not "objective" in principle (at least in the framework of the conception promoted here): they can be someone else's and for someone else only ${ }^{24}$, just like other significancies under discussion. The difference from values, which are "cardiological" in nature, is only in the fact that the kinds of my goods determined by my practical reason are much more similar to what it determines for others.

At that, the modalities of significancies cannot, of course, be thought of as "materially" isolated. A value that is absolute for someone today (the values of "cardiological" nature can be only absolute - see above) can transform to the area of the preferred only or even the non-preferred tomorrow with the inconstancy of the heart, and vice versa ${ }^{25}$. It is an issue of distinguishing the "forms" of these modalities proper, but not that of the changes to which their respective objects may be subject to. Nor are they "conflict-free": any developed person must constantly choose between desires of the heart and maxims of reason, and in many cases this choice leads to harsh conflicts, whereas preferences (as a kind of buffer zone between the values and the goods) provide a certain modus vivendi for the individual.

As a result, we can try to give a comparative definition of the goods based on intuition-

\footnotetext{
${ }^{24}$ One of the very few advocates of this understanding of the goods in analytical philosophy is R. Kraut, a specialist in Aristotle's practical philosophy, who successfully uses the historical and philosophical arsenal to develop modern topics. See: (Kraut, 2011).

${ }^{25}$ Not to mention, of course, that the same object may have different significances, preferences, goods, and values for different individuals. If you take such an ordinary case as renting an apartment at the moment, then for someone, who simply considers this form of earning money more convenient than other forms, it will be a preference; for someone who, when choosing from different opportunities, is guided by the fact that such earnings will give him more opportunities for self-realization in other areas of life or help someone else, it will be a good; and in the case of those, for whom regular income of money from the residents will be trembling and coveted (such cases also take place), we will deal with the value, "the space of bliss".
} 
ism or, in another way, the discretion of entities. It is reasonable to regard them as such a modality of personal significancies that can be described in the context of specific rationality, intersubjectivity, teleology, hierarchy, positivity, and eternity in some of its dimensions. To the greatest extent, they localize the individual's practical, ethical, and religious intentionality.

\section{Practical conclusions for practical philosophy}

From the mentioned above, it follows that there could be a correlation between axiology and agathology different from the one stated in the beginning of this article. Axiology, which has not yet overcome the crisis after Heidegger's criticism (see above), is now beyond the divisions of philosophy into the disciplines not only in the Anglo-American tradition but also in the Continent. These disciplines are divided mainly into theoretical, practical, and applied. One can make very serious claims to this division $^{26}$, but it is not possible to ignore it because of the lack of something better. It is difficult to find a place for the doctrine of values beyond

\footnotetext{
${ }^{26}$ Thus, applied philosophy (angewandte Philosophie) is an obvious oxymoron, since philosophy by definition can only be fundamental or none, and what is considered to be classical applied philosophy, such as bioethics, is only application of general ethical principles to specific situations, and nothing more. There is nothing "applied" in philosophy of science, philosophy of culture, philosophy of law, philosophy of art and other large "philosophies of something", which are usually included in this group. Practical philosophy is much better. This is not only because of its Aristotelian origin but also because it is clear that we mean a philosophical reflection on certain types of individual and social activities. However, this phrase can only be used conditionally, since any philosophy can be only theoretical.
}

anthropology (which is very difficult to fit into any of these "compartments", since it can be attributed to all the three), whereas the doctrine of the goods can be successfully integrated into both ethics and practical philosophy, of which ethics can be considered a part. The ethics based on the goods could constitute a very serious alternative to all three main programmes of theoretical ethics, i.e. virtue ethics, deontological ethics, and consequentialist ethics (with which it has external similarities ${ }^{27}$ ). Regarding the building of practical philosophy, agathology could form its foundation, since practice itself (in any field of human activity, except destructive one) can be defined as a way of realizing certain goods ${ }^{28}$. It is precisely because of its pronounced spiritual teleology that the agathological reason can be the main arbiter of goal-setting in any area of life, and it is precisely this that directs intelligent life as such.

\footnotetext{
${ }^{27}$ Similarities are shown in the following: consequentialism, which is utilitarianism in both its essence and origin, very readily operates with the notion of the goods. Yet, the good of consequentialists is, in fact, a mere well-being (it is not incidentally that a very influential element of this programme is called welfarism), whether it is thought only selfishly or even also socially. The highest goods for those, who are able to perceive them and strive for them, just come into conflict with well-being. The consequentialists' empirical criteria for the goodness of something cannot be accepted in agathological ethics also because it can deal with not only "verifiable" goods.

${ }^{28}$ Alasdair MacIntyre wrote about this in his main work. He defined practice as "any coherent and complex form of socially established cooperative human activity through which goods internal to that form of activity are realized in the course of trying to achieve those standards of excellence which are appropriate to, and partially definitive of, that form of activity, with the result that human powers to achieve excellence, and human concepts of the ends and goods involved, are systematically extended" (MacIntyre, 2007: 187).
}

\section{References}

Adams, R.M. (2006). A Theory of Virtue: Excellence in Being for the Good. Oxford, Oxford University Press.

Ammon, C.F. (1823). Handbuch der christlichen Sittenlehre. Bd. I. Leipzig, Georg Ioachim Göschen.

Beneke, F.E. (1828). Grundlegung zur Physik der Sitten: ein Gegenstück zu Kants Grundlegung zur Metaphysik der Sitten mit einem Anhange über das Wesen und die Erkenntnißgränzen der Vernunft. Berlin; Posen, Mittler.

Bentham, I. (1859). The Works. Vol.1. Edinburgh, William Tait.

Bond, E.J. (2001). Good, Theories of. In Encyclopedia of Ethics. L.C. Becker and C.B. Becker (Eds.). Vol. I. New York and London, Routledge, 620-624. 
Bränmark, J. (2006). Good, the. In: Encyclopedia of Philosophy. Second Edition. D.M. Borchert (Editor in Chief). New York, Gale, 150-153.

Delcomminette, S. (2006). Le Philebe de Platon: introduction à l'agathologie platonicienne. Philosophia Antiqua, 100. Leiden, Boston, Brill.

Edel, A. (1953). Concept of Values in Contemporary Philosophical Value Theory. In Philosophy of Science, 20 (3), 198-207.

Edel, A. (1992). Value. Theory of. In Encyclopedia of Ethics. L.C. Becker and C.B. Becker (Eds.). Vol. 2. New York, London, Routledge, 1269-1273.

Feder, J.G.H. (1770). Lehrbuch der praktischen Philosophie. Göttingen und Gotha, Johann Christian Dietrich.

Heidegger, M. (1997). Gesamtausgabe. I Abt. Heröffentliche Schriften 1910-1976. Bd.6:2. Nietzsche. Frankfurt am Main, Vittorio Klostermann.

Higgings, T.J. (2003). Moral Good. In: New Catholic Encyclopedia. T. Carson, J. Ceritto (Eds.). Vol. 6. Detroit, Gale, 350-354.

Hurka, T. (2007). Theory of Value. In The Oxford Handbook of Ethical Theory. D. Copp (Ed.). New York, Oxford University Press, 357-379.

Hutcheson, T. (1755). A System of Moral Philosophy. Two Volumes in One. Vol. 1. Glasgow: R. and A. Foulis.

Kant, I. (1903). Akademieausgabe von Kants Gesammelten Werken. Bd. IV. Berlin, Königlich Preussische Akademie der Wissenschaften.

Kirchner, F. (1911). Wörterbuch der philosophoschen Grundbegriffen. Neubearbeitung von Dr. C. Michaëlis. Leipzig, Verlag der Dürr'schen Buchhandlung.

Korsgaard, C. (1998). Goods Theories of the. In Routledge Encyclopedia of Philosophy. E. Craig (Gen. Ed.). Vol. 4. New York - London, Routledge, 130-135.

Kraut, R. (2011). Against Absolute Goodness. Oxford, Oxford University Press.

Külpe, O. (1910). Einführung in die Philosophie. Leipzig, Verlag von S. Hirzel.

Laird, J. (1929). The Idea of Value. Cambridge, Cambridge University Press.

MacIntyre, A. (2007). After Virtue: A Study in Moral Theory. Notre Dame (Ind), Univesity of Notre Dame Press.

Rickert, H. (1910). Vom Begriff der Philosophie. In Logos. 1910, 1-34.

Salamon, J. (2017). Agatheology and naturalisation of the discourse on evil. In International Journal of Philosophy and Theology, 78 (4-5), 469-484.

Shokhin, V.K. (2004) Agatologia (Agathology). In Filosofiia: Entsyclopeditheskii slovar'. Pod. red. A.A. Ivina [Philosophy: an Encyclopaedic Dictionary. Ed. by A. Ivin]. Moscow, Gardariki, 15-16.

Shokhin, V.K. (2006). Filosofiia tsennostei i ranniaia aksilogitcheskaia mysl' [Philosophy of Values and Early Axiological Discourse]. Moscow, People's Friendship University of Russia.

Shokhin, V.K. (2014). Agatologia: sovremennost' i klassika [Agathology: Modernity and the Classics]. Moscow, Canon+.

Wieser, J. von (1884). Über der Ursprung und der Hauptgeschichte der wirtschaftlichen Wert. Wien: A. Hölder. 


\title{
Аксиология и агатология
}

\section{B.К.Шохин}

Институт философии РАН

Российская Федерация, Москва

\begin{abstract}
Аннотация. Внимание с самого начала привлекается к тому факту, что термин аксиология, означающий учение о ценностях, будучи введенным в самом начале $\mathrm{XX}$ века, почти сразу повлек за собой целый бум разработок теорий ценностей (преимущественно в континентальной философии), тогда как термин агатология, означающий учение о благах и созданный в 1770, а затем открытый заново в 1823 году, пришел в почти полное забвение. С целью его реабилитации пересматривается одно из общих мест философии XX и XXI веков, а именно фактическое отождествление благ и ценностей, вследствие которого первое из этих понятий фактически поглощается вторым. Но то, что считается ценностями, также, как правило, клишированно понимается как общие человеческие потребности, а не глубинные и неделимые индивидуальные «внутренние обладания». Поэтому предлагается различать общечеловеческие потребности и личностные значимости и стратифицировать мир значимостей посредством дифференциации ценностей, преференций и благ. В результате последняя из этих разновидностей трактуется как сфера практического разума (в античном и в кантовском смыслах), телеологически нагруженная и могущая быть заложенной в новую, четвертую из больших программ теоретической этики (способную хорошо конкурировать консеквенционизмом, деонтологизмом и этикой добродетели) и одновременно в общий фундамент того кластера философских дисциплин, который принято называть практической философией.
\end{abstract}

Ключевые слова: ценности, предпочтения, блага, этика, практическая философия, аксиология, агатология, сердце, вкус, практический разум.

Научная специальность: 09.00.00 - философские науки. 